\title{
地球資源衛星データを用いた緑地環境分析
}

\section{An Analysis on Vegetation Cover by using LANDSAT Data}

村 井 俊 治*
建 石 隆太郎*
河 崎 和 明**

by Shunji Murai, Ryutaro Tateishi and

Kazuaki Kawasaki

\begin{abstract}
The study deals with two types of mathematical models for estimation of vegetation cover in Tokyo Districts from LANDSAT MSS digital data. Two types of models, multiregression model and parametric model were applied to the test area with ground surveyed data of vegetation cover collected in 1973 by the Ministry of Construction and geographically corrected LANDSAT MSS digital data, taken on 26th Nov. 1972. Multi-regression model is based on the average data in the unit area of so called " 500 meters mesh", while parametric model is based on each of pixels in the unit area.

From the results of the study, accuracies of the estimation for these two model were not remarkably different. Vegetation cover could be well estimated with the accuracy of 0.87 in multi-correlation coefficient, and $\pm 15 \%$ in standard deviation.
\end{abstract}

\section{和文梗概}

本研究は, 地球資源衛星 (LANDSAT) の MSS デ ィジタルデータから, 首都圈の緑地比率を推定するこ とが可能か否かを研究したものである。本研究では, 昭和 48 年に建設省が行った緑地現況調査で得られた 500 メートルメッシュの緑地比率データと, 昭和 47 年 11月26日にとられた LANDSAT データを用いて，2 種類の数字モデルにより, 緑地此率を推定した。これ ら数字モデルは500メートルメッシュの中に属す LANDSAT データの平均值を用いた重回帰モデルと, 500 メートルメッシュ内に属すデータの 1 点 1 点を用

*東京大学生産技術研究所

**建設省北陸地方建設事務所

「写真測量とリモートセンシング」Vol. 15 No. 4, 1976

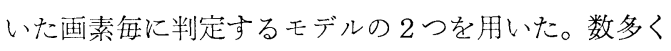
の異なる説明変量の組合わせに上る分析の結果, 最良 推定の精度は，上記 2 つのモデルともに大差はなく， 重相関係数で 0.87 , 標準偏差で約 $\pm 15 \%$ の推定が可能 であった。また緑地比率の定義を、スペクトル特性の 観点から行う方が害態とあっていることが指適され た。

\section{1. はじめに}

都市および都市近郊の緑地環境は, 都市の健全な姿 を監視するための一つの指標となっている。昭和 48 年 には，建設省が「首都 $50 \mathrm{~km}$ 圈緑地保存整備計画調査」 を行ない，首都圈の緑地現況図および緑地環境に関す る $500 \mathrm{~m}$ メッシュの数值データを作成した。この調査 においては, 航空写真が基礎資料として用いられ，多 大の費用と作業が必要とされた。 
本研究では，地球資源衛星 (LANDSAT) の MSS ディジタルデータのスペクトル特性とその広域同時性 に着目して，LANDSAT データから首都圈の緑地比 率を求めるための数学的モデルを作成しょうとした。 本研究の成果によれば, 緑地比率は, LANDSAT デ 一タから実用的に十分な, 高い精度で求めることが可 能であることがわかった。

\section{2. 使用データ}

\section{1 テスト地域}

図1に示した 5 万分の 1 の地図の「八王子」および 「東京西南部」をあわせた地域をテスト地域とした。 東西約 $45 \mathrm{~km}$ ，南北約 $18 \mathrm{~km}$ である。この地域の西部は 高尾および津久井の山岳部を含み，東部は品川抽よび 川崎の市街地を含み，中間部には丘陵や田畑などを含 んで扣り，緑地環境を検討するのに適当な内容をもっ ている。

\section{2 緑地比率の観測データ}

昭和 48 年の建設省による「首都 $50 \mathrm{~km}$ 圈緑地保存整 備計画調査」では, 表 1 に示されるような 16 項目の緑 地現況区分のデータが， $500 \mathrm{~m}$ メッシュごとに数值デ ータとして計測された。ここでいう $500 \mathrm{~m}$ メッシュと
は 5 万分の 1 の地図（経度間隔15分，緯度間隔10分） を縦横ともに 40 等分して得られる長方形のメッシュで 面積が約 $0.25 \mathrm{~km}^{2}$ ある。「八王子」および「東京西南 部」の地域をあわせると3,200個の500mメッシュがあ るが，一部に120個の久落データがあるので，3,080個 の緑地比率データが用いられた。データ值は\%単位で 0 から100までの整数がある。

建設省が定義した緑地比率は，表 1 に示されるよう に16項目のうちから「市街地」,「自然破壊地」, 「並 木」，「その他」が除かれたものの占める面積率をい う。しかし，この緑地比率は，例えば「水部」を含ん で扣り，スペクトル特性から見て緑地として扱らこと は妥当ではない。そこでスペクトル特性から見てょり 妥当な緑地比率データをつくることが必要である。本 研究では表 1 に示した補正緑地比率データが用いられ た。

補正緑地比率は, 建設省の定義した緑地比率からつ ぎのように補正された。

(1)「水部」のデータを除いた。

(2)「緑の多い市街地」(緑被率30\%以上の市街地) には少なくとも30\%の緑地があるとして，この分 をつ叮加えた。

(3)「荒地」の中には緑地がないものもあるので, 「荒地」の平均緑地被率が50\%であると仮定して 補正した。

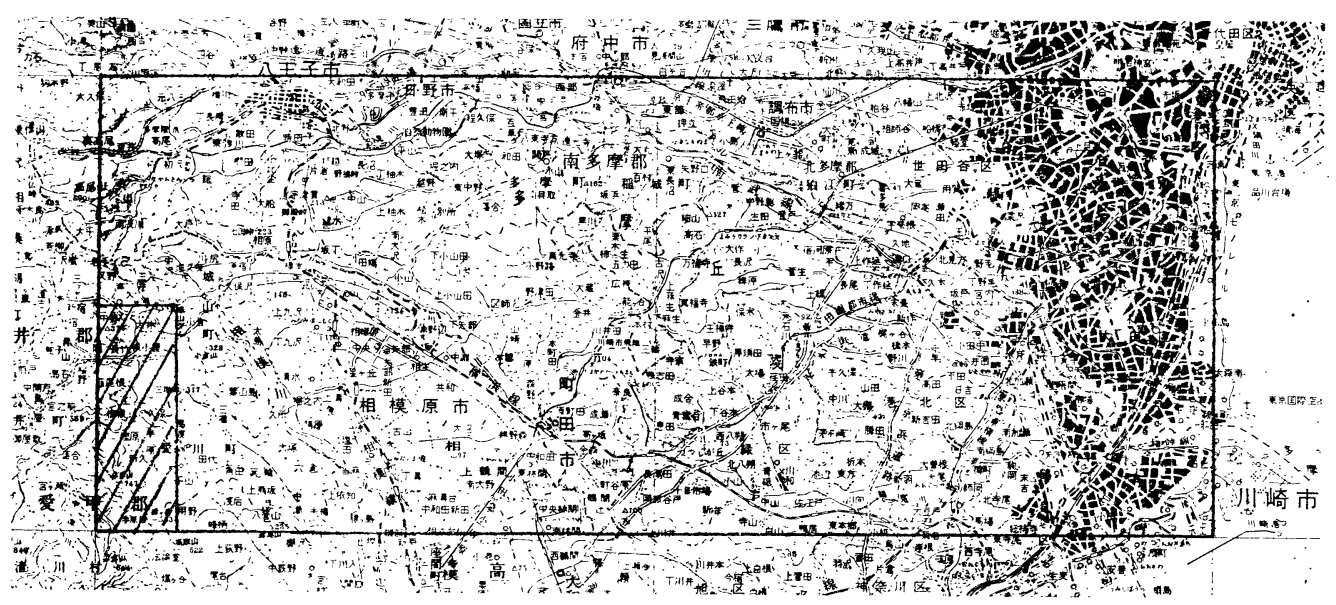

図 1 テスト地域（5万分の 1 地図「八王子」および「東京西南部」, 左下の斜線部は緑地比率データの欠落している ところを示す) 
本研究で使用した地球資源衛星 (LANDSAT) デー タは，昭和 47 年 11 月 26 日に撮影されたものである。こ のデータは，本テスト地域に叔いて，452×184 個の $100 \mathrm{~m}$ メッシュデータとして既に地理補正がなされて いる。その精度は最大誤差が約 1 画素, 約 $100 \mathrm{~m}$ である。 緑地比率観測データの $500 \mathrm{~m}$ メッシュと LANDSAT データの $100 \mathrm{~m}$ メッシとは区画が一致しないため, LANDSAT データの $100 \mathrm{~m}$ メッシュが緑地比率観測

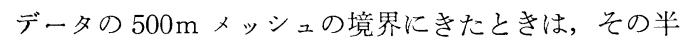
分以上が属する方の $500 \mathrm{~m}$ メッシュ含まれるとした。

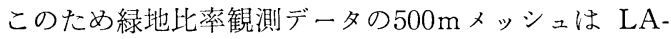
NDSAT データの100m メッシュにして，20〜30個に 対応する。

ここでは LANDSAT の MSS バンドのディジタ ルデータ $\boldsymbol{X}\left(x_{4}, x_{5}, x_{6}, x_{7}\right)$ を $500 \mathrm{~m}$ メッシュ毎に再編 集して，つぎにのべるモデルに入力できるようにし た。

\section{3. 緑地比率を推定するためのモデル}

\section{1 重回帰式による推定}

LANDSAT の 4 バンドのデータ $\boldsymbol{X}$ から導かれた $P$ 個の変数 $\boldsymbol{u}\left(u_{i} ; i=1, P\right.$ 例光ば $x_{4}$ それ自身あるいは $x_{3} / x_{4}$ など）の值を $500 \mathrm{~m}$ メッュ每に平均值をとり $500 \mathrm{~m}$ メッシュの緑地比率データ $y$ に対応させる。こ のとき，

$$
\begin{aligned}
y= & a_{0}+\sum_{i=1}^{P} a_{i} u_{i}+\varepsilon \\
& a_{0}: \text { 定数 } \\
& a_{i}: \text { 偏回帰倸数 } \\
& \varepsilon: \text { 誤差 }
\end{aligned}
$$

なるモデルを設定し，重回帰分析の結果から

$$
\hat{y}=\hat{a}_{0}+\sum_{i=1}^{P} \hat{a}_{i} u_{i}
$$

をもって，緑地此率を推定する。

\section{2 画素毎の判定による推定}

画素每の判定のモデルではまず最初に LANDSAT データXから, 緑地の有無を表現していると考兄られ る変数 $u$ を導き出す。つぎにこの変数があるパラメー タ $k$ の值を境として, 緑地であるか否かを画素每に識 别し 500m メッシュの中に緑地であると判定された画

\begin{tabular}{|c|c|c|}
\hline 緑地現況区分 & $\begin{array}{l}\text { 建設 省 } \\
\text { 粶地比率 }\end{array}$ & $\begin{array}{l}\text { 本研 究 } \\
\text { 補正緑地比率 }\end{array}$ \\
\hline 1. 針葉樹林（人工） & 1 & 1 \\
\hline 2. 針葉樹林（天然） & 1 & 1 \\
\hline 3. 広葉樹林 & 1 & 1 \\
\hline 4. 針広混交林 & 1 & 1 \\
\hline 5. 竹林 & 1 & 1 \\
\hline 6. 公園緑地 & 1 & 1 \\
\hline 7 . 水田 & 1 & 1 \\
\hline 8. 畑 & 1 & 1 \\
\hline 9. 園芸樹林 & 1 & 1 \\
\hline 10. 緑の多い市街地 & 0 & 0.3 \\
\hline 11. 緑の少ない本街地 & 0 & 0 \\
\hline 12. 並木 & 0 & 0 \\
\hline 13. 水部 & 1 & 0 \\
\hline 14. 荒地 & 1 & 0.5 \\
\hline 15. 自然破壊地 & 0 & 0 \\
\hline 16. その他 & 0 & 0 \\
\hline
\end{tabular}
素数の比率をもって緑地比率の推定量とする。このと き, $k$ の值を変えてみて, テスト地域に打ける推定值
表 1 緑地現況区分之緑地比率の定義

(係数を乗じた総和の面積率を緑地比率とする)

と観測値との残差の 2 乗和を最小とするような $k$ の值 を求め, この $k$ に対応する緑地比率を最良推定值とす る。

\section{3 モデルの優良性の評価基準}

本研究ではモデルの優良性を統一的に評価するの に, 平均 2 乗誤差の平方根 $Z$ を用いた。

$$
\begin{aligned}
& Z=\sqrt{\frac{\sum_{i=1}^{n} \varepsilon_{i}{ }^{2}}{n}} \\
& n: \text { サンプル数 }
\end{aligned}
$$

一般に重回帰分析において，そのあてはめ精度の評 価に重相関係数が用いられる。同一サンプルにおい て，目的変数を変えずに，説明変数をいろいろ変えて 重回帰分析を行らとき，重相関数が大きくなれば $Z$ は 小さくなり，またその逆も言兄る。そこで重回帰モデ 几内の評洒基準には主として重相関数を用いて相対的

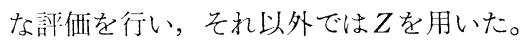




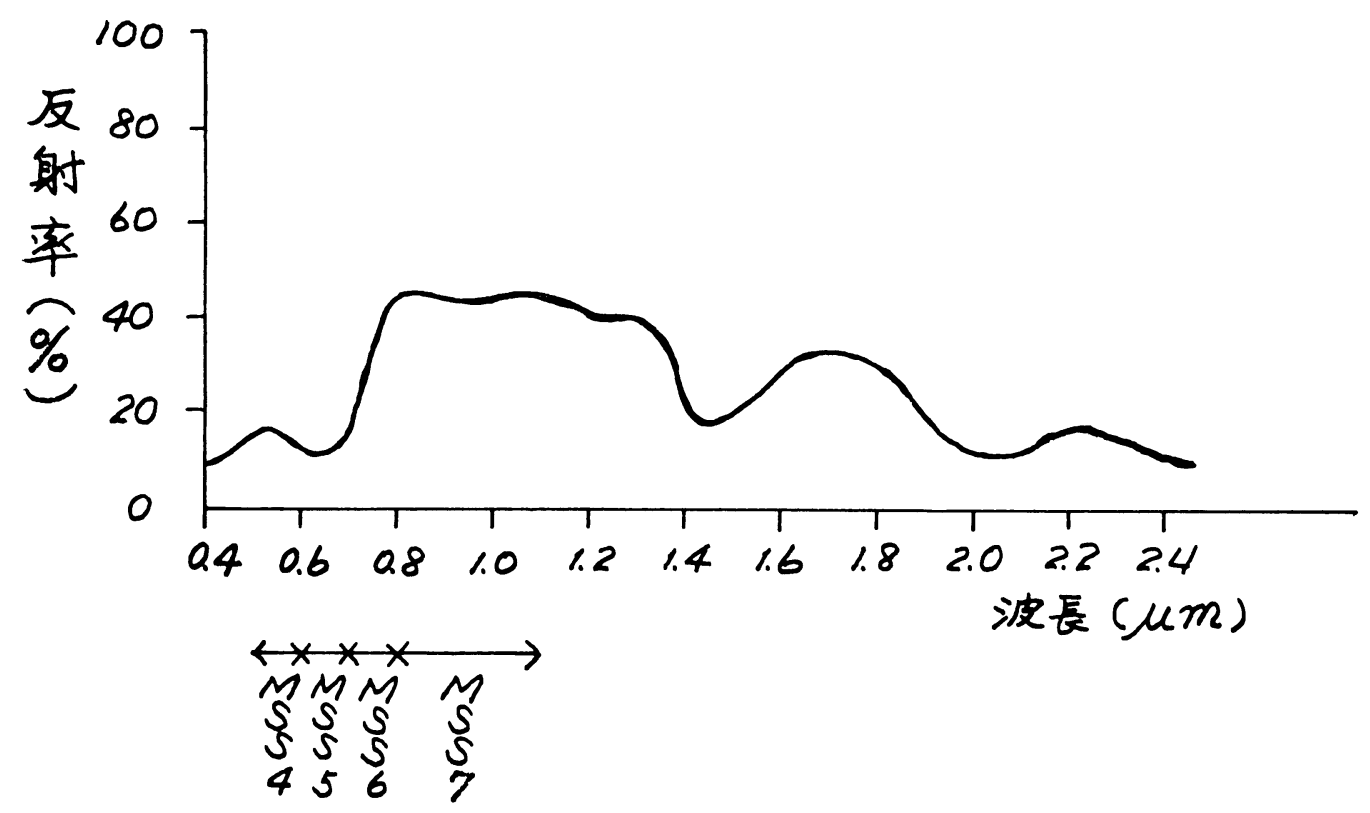

図 2 植物の典型的なスペクトル特性

\section{4. 重回帰式による推定}

\section{1 最適な説明変数}

植物は図 2 に示すような反射特性をもっている。地 上の地物を水・植物・無機物の 3 つに大きく分類した とき，LANDSAT データにおいてこれらの地物は図 3 に示すような典型的な特徵をもつ。端的にいって, 植物のスペクトル特性のパターンは， 4,5 バンドか ら6，7 バンドにかけての傾きが大であるといえる。

以上のことに注目して 9 種類の変数をえらび55組の 異なる説明变数の組合わせに対して重回帰分析を行っ た。結果の良かった組だけを10組とりだし表 2 に示 于。

これらの結果を見ると, 特にすぐれた説明変数の組 はなく，いずれも重相関係数が 0.87 以上である。もっ とも重相関係数の高かった説明变数の組は $\left(x_{7} / x_{4}, x_{5}\right.$, $\left.x_{6}\right)$ であった。この場合の緑地比率の推定值を図 5 に, $20 \%$ ごとの 5 段階に分けて示した。図 4 は緑地比率の 観測值を同様に示したものである。

\section{2 残差の主要原因}

説明変数 $\left(x_{7} / x_{4}, x_{5}, x_{6}\right)$ の場合の推定に拈いて, 残

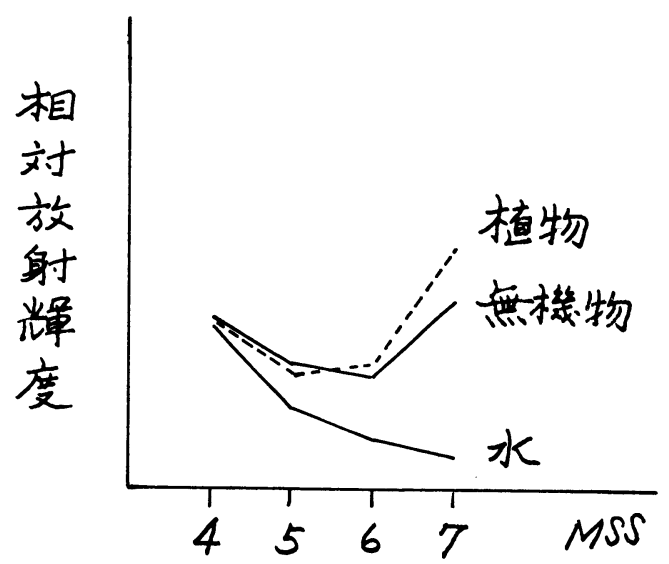

図 3 LANDSAT データの輝度レベルにおける スペクトル特性 
表 2 重回帰分析において選ばれた説明変数の組

\begin{tabular}{|l|c|c|}
\hline \multicolumn{1}{|c|}{ 明変 説 } & 重 相 関 係 数 & 評 価 基 準 $z$ \\
\hline$x_{4}, x_{5}, x_{6}, x_{7}$ & 0.875 & $15.52^{*}$ \\
$x_{7} / x_{4}, x_{5}$ & 0.878 & $15.16^{* *}$ \\
$x_{7} / x_{4}, x_{5}, x_{6}$ & 0.878 & \\
$x_{7} / x_{5}, x_{4}, x_{7}$ & 0.875 & \\
$x_{6}+x_{7} / x_{4}+x_{5}, x_{5}, x_{7}$ & 0.877 & \\
$x_{6} / x_{5}, x_{4}, x_{5}, x_{7}$ & 0.876 & \\
$x_{7} / x_{5}, x_{4}, x_{5}, x_{7}$ & 0.876 & \\
$x_{6}+x_{7} / x_{4}+x_{5}, x_{4}, x_{5}, x_{7}$ & 0.877 & \\
$x_{6} / x_{5}, x_{4}, x_{5}, x_{6}, x_{7}$ & 0.876 & \\
$x_{7} / x_{5}, x_{4}, x_{5}, x_{6}, x_{7}$ & 0.877 & \\
\hline
\end{tabular}

* 説明変数 $\left(x_{4}, x_{5}, x_{6}, x_{7}\right)$ のときの重回帰式 $\hat{y}=-3.34 \times x_{4}-5.23 \times x_{5}+3.24 \times x_{6}+6.34 \times x_{7}+83.42$

** 説明変数 $\left(x_{7} / x_{4}, x_{5}, x_{6}\right)$ のときの重回帰式 $\hat{y}=175.6 \times x_{7} / x_{4}-4.35 \times x_{5}+1.68 \times x_{6}+8.42$

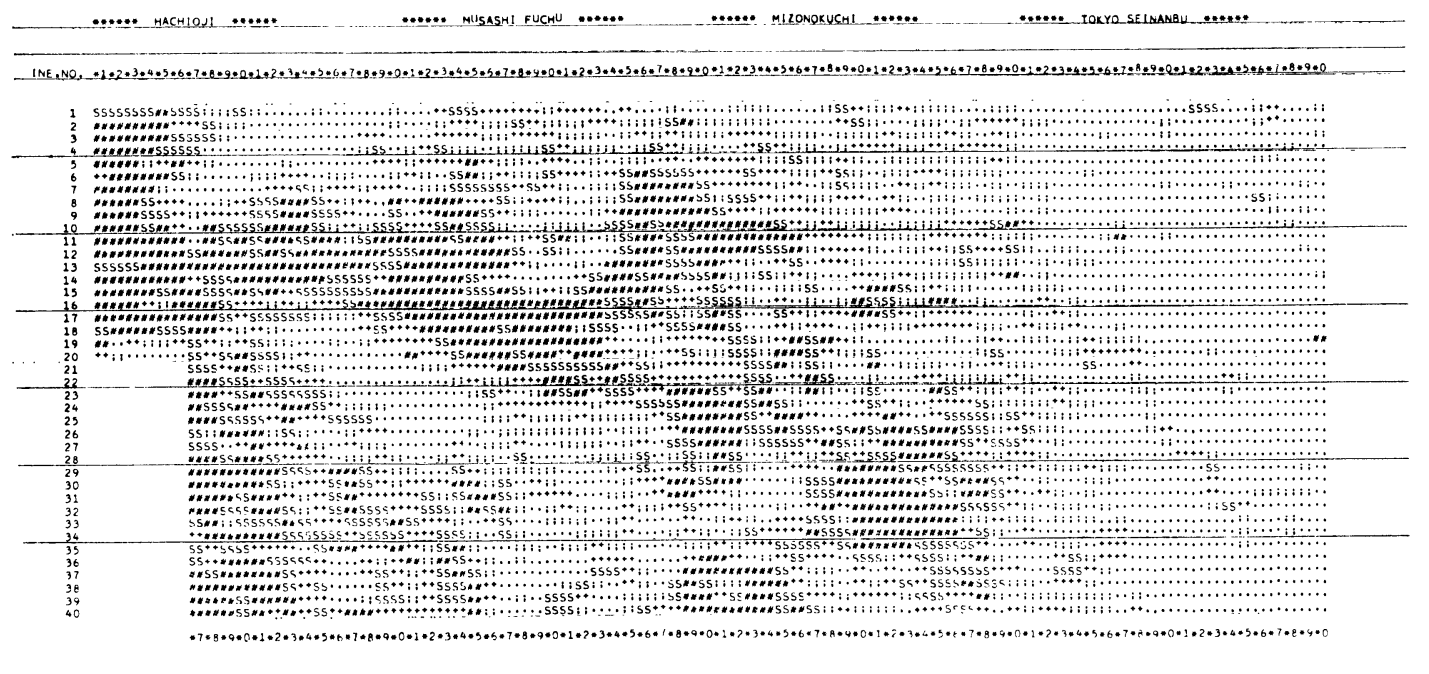

$$
\begin{array}{lll}
\cdot(0 \sim 20 \%) & ; ;(21 \sim 40 \%) & ++(41 \sim 60 \%) \\
& \text { SS }(61 \sim 80 \%)
\end{array}
$$

\section{図 4 緑地比率の観測値}




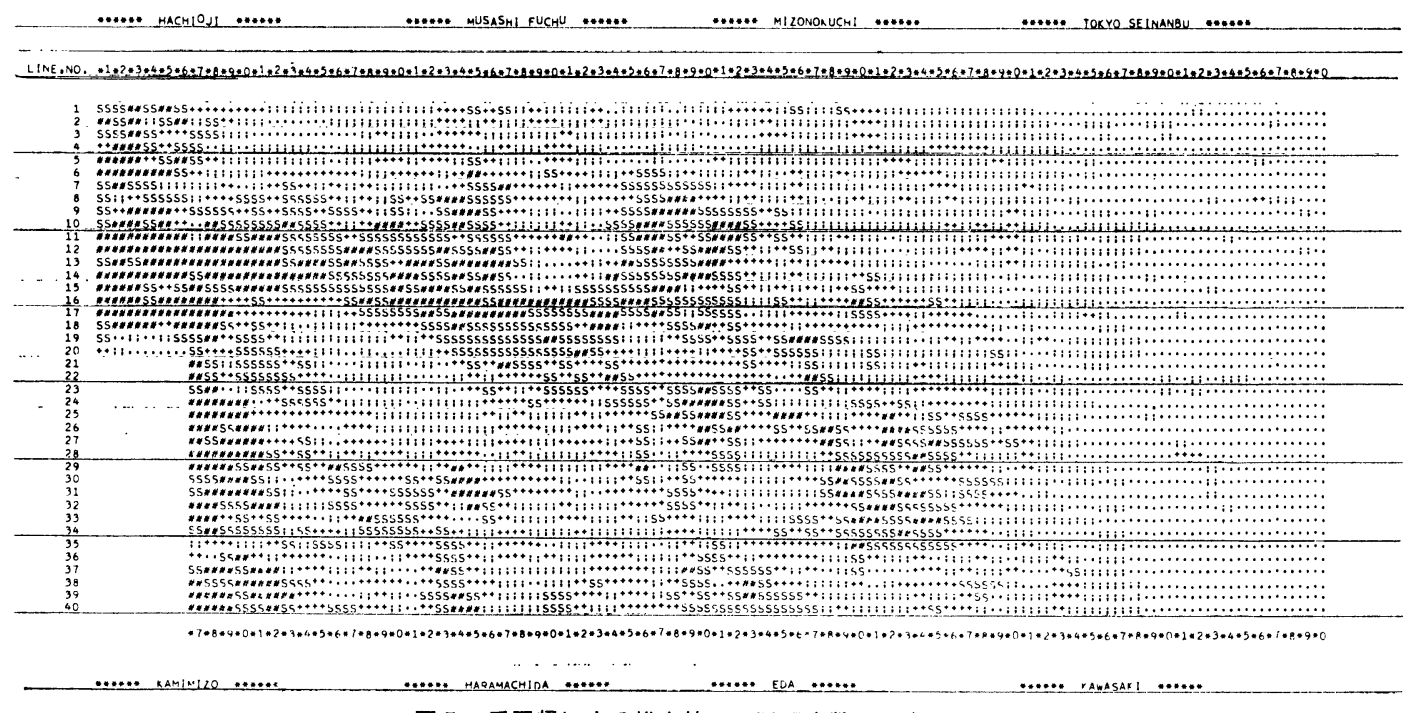

説明变数 : $x_{7} / x_{4}, x_{5}, x_{6}$

差（観測値一推定值）の絶対值が31以上のメッシュは 3,080個中123個（約 4\%）あった。これらのメッシュ について調べてみると次のことが指摘される。

（1）公園, 田畑, 山岳部では推定值が観測值より小 さい值を示す傾向がある。これは公園，田畑にお いては, 緑がない部分があるにもかかわらず緑地 比率の定義上，緑地比率の観測データに算入され ているためである。山岳部においては，山の影が スペクトルデータ LANDSATに影響を与えて, 緑であるにもかかわらず，LANDSAT データで は緑として認識されなかったためである。

（2）自然破壊地においては，推定值が観測値より大 きい值を示す傾向がある。これは自然破壊地には 若干の緑があるにもかかわらず，緑地比率の定義 上, 緑地比率の観測データに算入されなかったた めである。

建設省で定義された緑地比率はスペクトル特性的に 妥当でないため, 本研究では補正した緑地比率を観測 データとして用いた。しかし，補正した緑地比率で も,な拉ペクトル特性的に妥当でない部分があっ た。すなわち，植物があるにもかかわらず緑地比率に 算入されていない，また逆に，植物がないにもかかわ
らず緑地比率に算入されている。上の(1)(2)でもわかる ように, 残差の主要原因は, 緑地比率の定義に起因し ている。したがって LANDSAT データから推定され た緑地比率の方がもしろ緑地の現況に近い緑地比率を 示しているといってよい。図6 6 は, 緑地此率の観測值 と推定值の比較を行らために描かれた断面図である。 この図を見ると以上の説明が良くわかるであろう。

\section{5. 画素毎の判定による推定}

\section{1 最適な説明変数}

この推定方法においては，「3．2」で述べたよう に緑地の有無を表現していると考えられる変数を選 び出すことが必要である。そこで図 2 , 図 3 の植物の 反射特性に注目にして表 3 に示した 7 種類の変数を採 用した。これらの各々の変数において最良パラメータ $k$ を求め, モデルの優良性を評価した結果, 説明変数 $\left(x_{6} / x_{5}\right)$ が最適な説明変数であることがわかった。こ の場合の緑地比率の推定值を図 7 に，20\%ごとの 5 段 階に分けて示した。

\section{2 残差の主要原因}

説明変数が $\left(x_{6} / x_{5}\right)$ の場合に括いて, 残差を調べた 

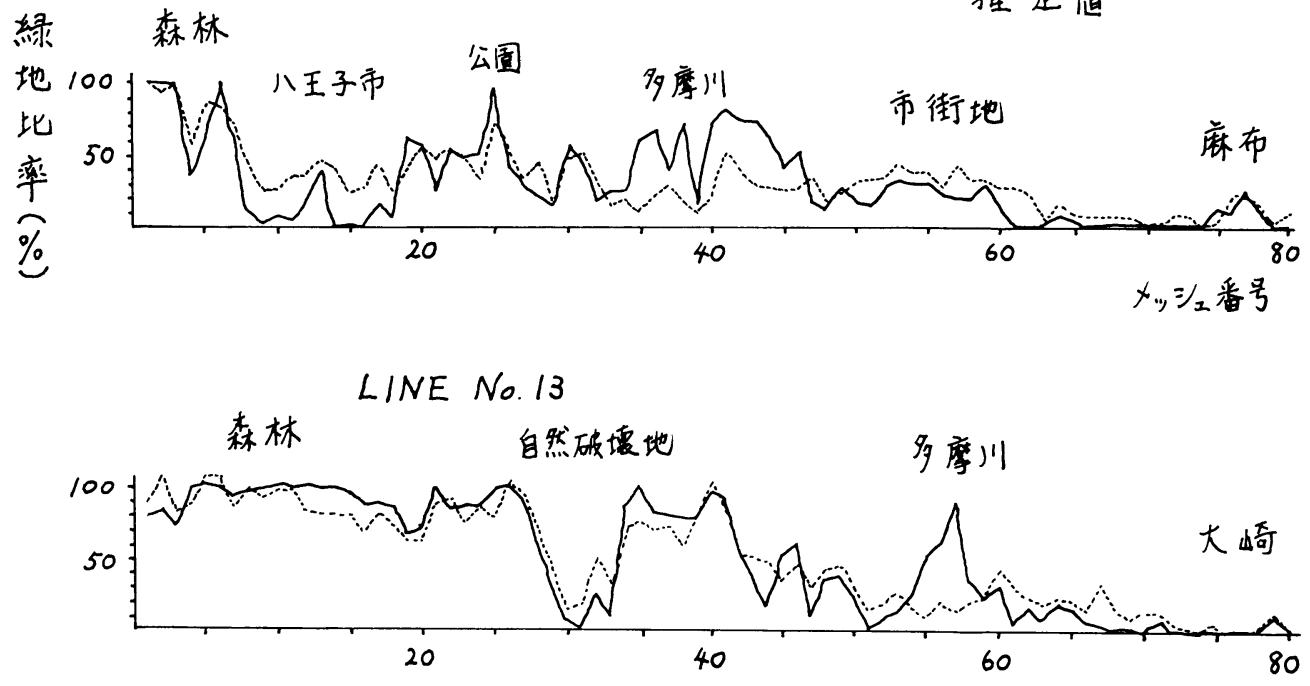

LINE No. 25

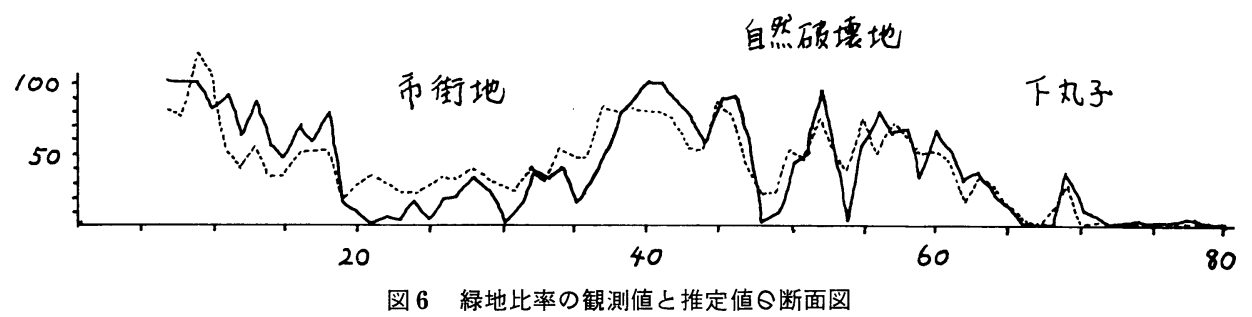

表 3 「画素毎の判定による推定」におけるパラメータ $\boldsymbol{k}$ の決定と評価基準 $z$

\begin{tabular}{|c|c|c|c|c|c|}
\hline 説 & 明 & 変 数 & パラメータ $k$ & 評価基準 & $z$ \\
\hline \multicolumn{3}{|c|}{$x_{6} / x_{4}$} & 0.94 & 20.05 & \\
\hline \multicolumn{3}{|c|}{$x_{7} / x_{4}$} & 0.45 & 18. 13 & \\
\hline \multicolumn{3}{|c|}{$x_{6} / x_{5}$} & 1.14 & 15.26 & \\
\hline \multicolumn{3}{|c|}{$x_{7} / x_{5}$} & 0.57 & 16. 12 & \\
\hline \multicolumn{3}{|c|}{$x_{6}+x_{7} / x_{4}+x_{5}$} & 0.76 & 16. 66 & \\
\hline \multicolumn{3}{|c|}{$x_{4}+x_{5}-x_{6}-x_{7} / x_{4}+x_{5}+x_{6}+x_{7}$} & 0.14 & 16.75 & \\
\hline \multicolumn{3}{|c|}{$u$} & -0.1 & 16.58 & \\
\hline
\end{tabular}

ここで $u$ は説明変数 $\left(x_{4}, x_{5}, x_{6}, x_{7}\right)$ による緑地比率の重回帰推定式である。 $u=-3.34 \times x_{4}-5.23 \times x_{5}+3.24 \times x_{6}+6.34 \times x_{7}+83.42$ 


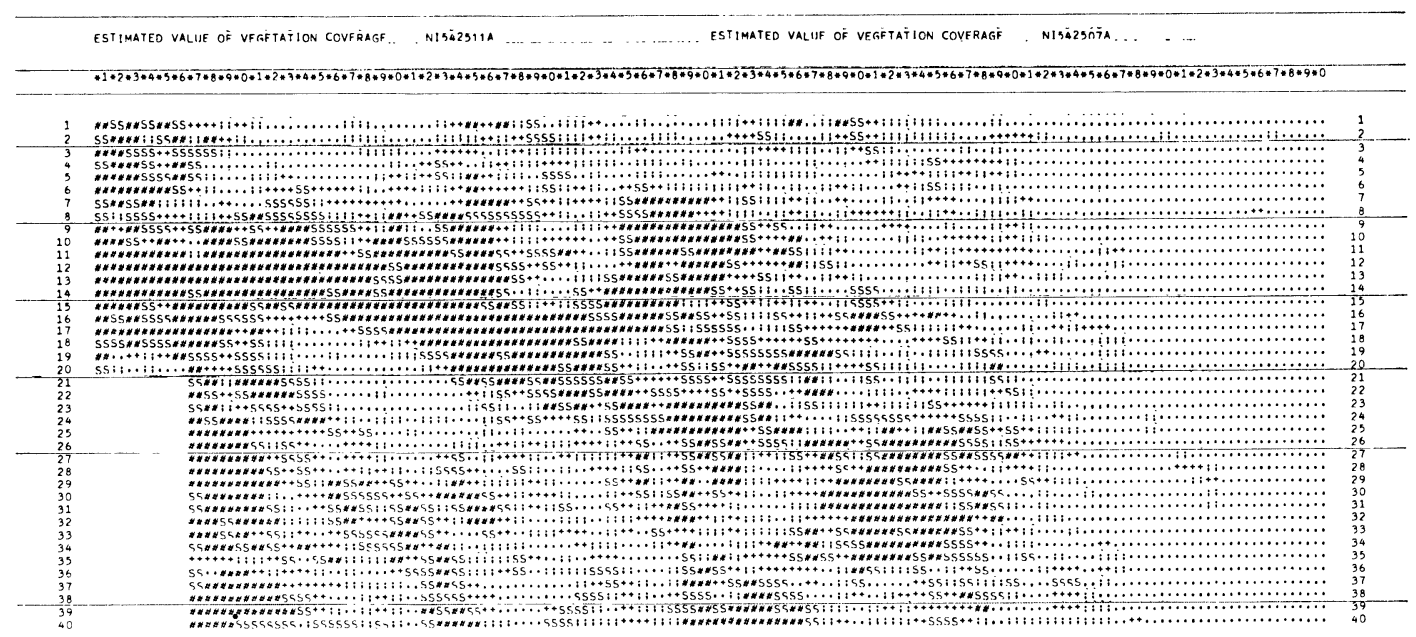

図 7 画素毎の判定による推定值 説明变数 : $\boldsymbol{x}_{6} / \boldsymbol{x}_{5}$

が，大きな残差の内容は，重回帰式による推定の場合 と同じ傾向を示した。その大部分は，緑地比率の観測 データが正しく植物の有無を示していないことに起因 する。

\section{6.「重回帰式による推定」と「画素毎の 判定」による推定との比較}

つぎに「重回帰」方式と「画素毎の判定」方式との 特徵や相違を考察してみよう。

(1)「重回帰」方式では，LANDSAT データを500 $\mathrm{m}$ メッシュの緑地比率の観測データに対応させる ために, $500 \mathrm{~m}$ メッュ内の平均値を用いている。 これに対し,「画素毎の判定」方式では, 画素(100 $\mathrm{m}$ メッシュデータ) ごとに緑地か否かを判定して いる。

(2)「重回帰」方式では説明変数を観測データのメ ッシュに対応させる必要があるため, 上り解像力 の高いリモート・センシング・データが得られて もそれを生かしきれない。この点,「画素毎の判 定」方式では，リモート・センシング・データの 解像力に応じて精度を上げることができる。

(3) 両方式による推定推度は注汸同等である。また
大きい残差の傾向も同じで，原因は緑地比率の定 義による。

\section{7. まとめ}

(1) LANDSAT データから求められた緑地比率は, 緑地の現況をきわめてよく表現している。

（2）従来の緑地比率の定義を再考する必要がある。 リモートセンシングデータの有効利用をはかる上 で，スペクトル特性から緑地を定義することを提 言したい。すなわち，本研究によれば，放射輝度 レベルで近赤外バンド (MSS 6)が赤バンド (MSS 5）より大となる点 (LANDSAT の CCT データ では $x_{6} / x_{5}>1$. 14tる点) を緑地之認めてよい。 これは植物の有するクロロフィルの赤バンドにお ける吸収と近赤外バンドに怙汀る反射の特性から も十分合理性をもっていると考光られる。すなお ち, $\mathrm{CCT}$ データ $x$ を輝度レベルに変換したとき， 赤外バンド（MSS 6）と赤バンド（MSS 5) の比 は, $1.76 x_{6} / 2.00 x_{5}$ で与兄られ，この比が 1 に なるときの CCT データの比は

$$
x_{6} / x_{5}=2.00 / 1.76=1.14
$$

となり，最良パラメータ $k$ の值と一致する。結局, 輝度レベルで, MSS 5 と MSS6で正の勾配を有 するとき緑地であると考兄て妥当である。 
（3）本研究では，季節による影響を考慮しなかった が，植物にクロロフィルの多く含まれている夏に は精度が高く，逆に冬には精度が低くなることは
容易に想像できる。季節ごとの LANDSAT デー タが入手できれば，緑地比率を推定する上で最適 な季節が決定できるだろう。 